\title{
Small Intestine and Liver Microsomal Triacylglycerol Transfer Protein in the Bovine and Rat: Effects of Dietary Coconut Oil
}

\author{
B. Graulet, D. Gruffat, D. Durand, and D. Bauchart \\ Unité de Recherches sur les Herbivores, \\ Equipe Nutriments et Métabolismes, \\ Institut National de la Recherche Agronomique, \\ Centre de Recherches de Clermont Ferrand-Theix, \\ 63122 Saint-Genès Champanelle, France
}

\begin{abstract}
The bovine liver is characterized by a chronic low capacity to secrete triacylglycerols (TAG). In situations favoring their hepatic synthesis, such as coconut oil feeding, TAG accumulate, leading to a lipid infiltration in the liver of preruminant calves. To assess the possible role of the microsomal TAG transfer protein (MTP) in this phenomenon and to put into evidence a tissuespecific regulation in the bovine species, we compared by Western blot the content in both MTP subunits in the liver and in different portions of the small intestine in preruminant calves and in growing rats receiving coconut oil or beef tallow as the sole source of fat in the diet. The pattern of MTP distribution was similar between calf and rat tissues, the jejunum being the major site for both MTP expression and intestinal absorption of dietary lipid endproducts. Concentrations of the MTP large and small subunits were 10- to 20fold lower and 2- to 3-fold lower, respectively, in calf than in rat tissues, including the liver. Coconut oil in the diets of calves and rats did not significantly affect the expression of MTP large subunits even though TAG content was strongly increased 12 -fold in the calf liver. These results clearly indicated that calf liver handled fat metabolically in a manner different from rat liver. However, present experimental conditions did not allow proof that MTP was directly related to the accumulation of fat in calf liver.
\end{abstract}

(Key words: coconut oil, liver, microsomal triacylglycerol transfer protein, small intestine)

Abbreviation key: apo $\mathbf{B}=$ apolipoprotein B, BT = beef tallow, $\mathbf{C O}=$ coconut oil, $\mathbf{D A U}=$ densitometric arbitrary unit, FA = fatty acids, $\mathbf{M T P}=$ microsomal triacylglycerol transfer protein, $\mathbf{P D I}=$ protein disulfide

Received December 9, 2003.

Accepted July 1, 2004.

Corresponding author: D. Gruffat; e-mail: gruffat@clermont. inra.fr. isomerase, $\mathbf{T A G}=$ triacylglycerol, $\mathbf{V L D L}=$ very low density lipoprotein.

\section{INTRODUCTION}

The microsomal triacylglycerol (TAG) transfer protein (MTP) was first purified from hepatic microsomes of bovine animals, and its biological role is characterized by in vitro experiments showing that MTP possesses an activity of lipid transport between membranes (Bakillah and El Abbouyi, 2003). Microsomal TAG transfer protein is a heterodimer composed of 2 distinct protein subunits; the largest subunit $(97 \mathrm{kDa})$ alone has no intrinsic activity, whereas the smallest one (58 $\mathrm{kDa}$ ) corresponds to a previously described enzyme, the protein disulfide isomerase (PDI; EC 5.3.4.1) (Wetterau et al., 1990). As a free form, PDI allows the folding of newly synthesized proteins by participating in the formation of disulfide bonds, but PDI is also implicated in several proteic complexes, explaining its large domain of expression among tissues (De Lorenzo and Molea, 1967; Brockway et al., 1982; Mikami et al., 1998). In contrast, MTP activity has been characterized mainly in the liver and the small intestine of the bovine and the rat (Wetterau and Zitversmit, 1986), tissues in which the specific expression of the large subunit was more recently demonstrated in human (Shoulders et al., 1993), hamster (Lin et al., 1994), and mouse (Nakamuta et al., 1996).

Several arguments sustain the hypothesis that MTP activity could be involved in the transfer of TAG from their site of synthesis on the membrane of the endoplasmic reticulum to the site of very low density lipoproteins (VLDL) assembly, in the lumen of the endoplasmic reticulum. Indeed, recent findings have shown that MTP was able to interact with nascent apolipoprotein B (apo B), the main apolipoprotein component of VLDL particles, acting both as a chaperone protein and as a source of TAG (Bakillah and El Abbouyi, 2003). A reduction of MTP activity has also been correlated to the development of alcoholic fatty liver in rats (Sugimoto et al., 2002). Moreover, in patients suffering from genetic abe- 
talipoproteinemia, the defect in intestinal and hepatic production of apo B-containing lipoproteins has been correlated to the lack of efficient MTP activity (BerriotVaroqueaux et al., 2000). Conversely, the cotransfection of apo B with a functional MTP in a heterologous system (COS-1 from hamster ovary, HeLa cells from human hepatoma, or Sf-21 insect cells) allowed secretion of apo B-containing lipoproteins (Wetterau et al., 1997). Despite the fact that MTP protein appeared necessary for the assembly and secretion of lipoproteins containing apo B, the effects of nutritional factors on MTP activity have been relatively less studied. In rodents, hepatic MTP activity increased with increasing amounts of dietary fats (Lin et al., 1994; Bennett et al., 1995; Tagushi et al., 2002). In the liver, this is especially marked when the diet is rich in saturated fatty acids (FA) (Bennett et al., 1995). Additionally, it has been shown that cholesterol (Bennett et al., 1996; Billett et al., 2000) or a sucrose-rich diet (Lin et al., 1994) also increased the mRNA level of MTP large subunit in the liver of hamsters.

In bovine animals, the liver has a low ability to secrete TAG as part of VLDL particles (Emery et al., 1992), especially when compared with other species, such as rat (Pullen et al., 1990). We have demonstrated previously that the differences in FA metabolism (Graulet et al., 1998) and apo B synthesis (GruffatMouty et al., 1999) between bovine and rat species could not explain the discrepancy in VLDL production rates observed between these 2 species. At the same time, comparison of liver MTP activity between several species, including rat and bovine (Bremmer et al., 1999), showed no relationship between hepatic MTP activity and TAG export abilities in general metabolic conditions. However, such comparisons were not made in metabolic situations where TAG accumulate in the liver. In high-producing dairy cows in negative energy balance during early lactation, the low ability to secrete TAG led to the development of a liver steatosis when the rate of FA uptake was intense (Gruffat et al., 1997). Presently, it is not known what limits VLDL secretion in ruminants. However, several factors participating in the synthesis of the VLDL components and in their subsequent assembly, such as the nature of the FA esterification products, TAG partitioning between cytosolic droplets and microsomal pools, TAG hydrolysis by the cytosolic lipase followed by reesterification inside the reticulum by the diacylglycerol-acyltransferase, apo $B$ balance between synthesis and degradation, and lipidation of apo B by microsomal TAG under the MTP activity, could be involved in the regulation of VLDL secretion, as previously reviewed by Chen and Grummer (2001). Recently, it was observed in dairy cow liver that MTP activity decreased on the days before calving, concomitantly with the increase in liver TAG content (Bremmer et al., 2000a). Moreover, those researchers have demonstrated that MTP activity was not modulated by the increase in liver TAG content occurring after a large FA uptake, both in vivo and in vitro (Bremmer et al., 2000b).

In the preruminant calf, the replacement of a standard source of lipid, i.e., beef tallow (BT), in the milk diet by coconut oil $(\mathbf{C O})$ rich in saturated FA (Jenkins and Krammer, 1986; Bauchart et al., 1999), or by soybean oil rich in n-6 polyunsaturated FA (Leplaix-Charlat et al., 1996), also led to the development of a TAG infiltration in the liver. These data suggest that not only the amount but also the composition of FA taken up by the liver could induce the development of fatty liver in bovine animals. In vitro experiments conducted in our laboratory showed that the administration of $\mathrm{CO}$ for $3 \mathrm{wk}$ to calves reduced FA oxidation, stimulated their esterification in hepatocytes (Graulet et al., 2000), and decreased hepatic apo B content and VLDL secretion (Gruffat-Mouty et al., 2001). Given these factors, and based on the results available in the literature cited previously suggesting a correlation between MTP activity and VLDL secretion and its potential regulation of expression by FA content and composition, we tested the hypothesis of the role of MTP as a limiting factor for VLDL secretion in the bovine species.

Thus, the aim of this work was 1) to describe precisely the distribution of MTP in the liver and in the small intestine of calf and of growing rat to determine whether the low secretion rate of VLDL by calf liver might be explained by a tissue specificity or an animal species characteristic, and 2) to analyze the effect of $\mathrm{CO}$ feeding on the hepatic MTP content in preruminant calves and growing rats to determine whether MTP might be a limiting factor for TAG secretion involved in the induction of the liver steatosis that occurs in COfed calves.

\section{MATERIAL AND METHODS}

\section{Reagents}

Milk replacers were supplied by Bridel Retiers Society (Bourg Barré, France); peptidase inhibitors, sucrose, and EDTA were purchased from Sigma Chemical Corp. (St. Louis, MO); and Acrylogel 2.6 was from BDH Laboratory supplies (Poole, UK). Molecular weight markers were supplied by Bio-Rad (Munich, Germany), and membranes for immunoblot were purchased from Millipore (Bedford, MA). The ECL Western blotting kit and multipurpose hyperfilms were supplied by Amersham International (Bucks, UK); chloroform, methanol, and isopentane were supplied by Prolabo (Paris, 
Table 1. Composition of experimental diets.

\begin{tabular}{|c|c|c|}
\hline & Beef tallow & Coconut oil \\
\hline Ingredient & \multicolumn{2}{|c|}{$\longrightarrow(\%$ of $\mathrm{DM}) \longrightarrow$} \\
\hline Spray-dried skim milk powder & 71.6 & 71.6 \\
\hline Tallow & 22.4 & - \\
\hline Coconut oil & - & 22.4 \\
\hline Corn starch & 5.0 & 5.0 \\
\hline Vitamin and mineral mixture $^{1}$ & 1.0 & 1.0 \\
\hline Fatty acid composition & \multicolumn{2}{|c|}{ - (g/100 $\mathrm{g}$ of total fatty acids $)$} \\
\hline \multicolumn{3}{|l|}{ Saturated fatty acids } \\
\hline $8: 0$ & 0.1 & 0.6 \\
\hline $10: 0$ & 0.1 & 4.0 \\
\hline $12: 0$ & 2.9 & 42.4 \\
\hline $14: 0$ & 4.2 & 17.9 \\
\hline $16: 0$ & 22.3 & 12.8 \\
\hline $18: 0$ & 19.2 & 5.0 \\
\hline \multicolumn{3}{|l|}{ Monounsaturated fatty acids } \\
\hline $16: 1 n-7$ & 2.4 & 0.5 \\
\hline $18: 1 n-9$ & 37.8 & 12.1 \\
\hline \multicolumn{3}{|l|}{ Polyunsaturated fatty acids } \\
\hline $18: 2 n-6$ & 2.4 & 3.0 \\
\hline $18: 3 n-3$ & 0.4 & 0.3 \\
\hline Saturated:unsaturated ratio & 1.13 & 5.20 \\
\hline
\end{tabular}

${ }^{1}$ The vitamin and mineral mixture contained (per $\mathrm{kg}$ of mixture) $0.15 \mathrm{~g} \mathrm{MgSO}_{4}, 0.30 \mathrm{~g} \mathrm{MgO}, 8 \mathrm{mg} \mathrm{FeSO}{ }_{4}, 10 \mathrm{mg} \mathrm{CuSO}_{4}, 80 \mathrm{mg} \mathrm{ZnSO}_{4}$, $48 \mathrm{mg} \mathrm{MnSO} 4,0.6 \mathrm{mg} \mathrm{CoSO}_{4}, 0.18 \mathrm{mg} \mathrm{CaI}_{2}, 0.15 \mathrm{mg} \mathrm{Na}_{2} \mathrm{SeO}_{3}, 25,000$ IU retinol, 5000 UI cholecalciferol, $50 \mathrm{mg} \alpha$-tocopherol, $5 \mathrm{mg}$ thiamine, $10 \mathrm{mg}$ riboflavine, $25 \mathrm{mg}$ panthothenic acid, $40 \mathrm{mg}$ niacin, $0.08 \mathrm{mg}$ cyanocobalamin, $4 \mathrm{mg}$ pyridoxine, $2.5 \mathrm{mg}$ menadione, $100 \mathrm{mg}$ ascorbic acid, $0.1 \mathrm{mg}$ biotine, $1.2 \mathrm{mg}$ folic acid, $0.6 \mathrm{~g}$ methionine, $0.8 \mathrm{~g}$ lysine chloride, $0.8 \mathrm{~g}$ choline, $0.05 \mathrm{~g}$ virginiamycin, and $3 \mathrm{~g}$ sorbitol (Celtic Langlois, St. Jacques de la Lande, France).

France); and Oil Red O was from Merck (Darmstadt, Germany).

\section{Animals and Diets}

Fourteen preruminant Holstein $\times$ Friesian male calves (15 d old; $50.7 \pm 2.2 \mathrm{~kg}$ ) were divided into 2 groups matched in age and BW. Each group, after $7 \mathrm{~d}$ of adaptation, received a conventional milk-based diet containing $22.4 \%$ lipids (on a DM basis) given either in the form of BT or CO, for $19 \mathrm{~d}$. Chemical composition of the milk diets, including FA composition of the lipid sources, is given in Table 1 . During the first $7 \mathrm{~d}$ of the experiment, calves were adapted to the diet, given feed corresponding to an average daily weight gain of 0.65 $\mathrm{kg} / \mathrm{d}$ for both diets, as recommended by Toullec (1978). From d 8 through 19, calves were given the experimental diets to reach an average daily weight gain of 1.1 $\mathrm{kg} / \mathrm{d}$ (Toullec, 1978). Calves were fed 4 times (2200, 0100,0400 , and $0700 \mathrm{~h}$ ) on the night before the experiment to ensure a constant postabsorptive state (Durand and Bauchart, 1986).

Sixteen suckling Sprague-Dawley rats ( $21 \mathrm{~d}$ old; 80.1 $\pm 1.2 \mathrm{~g}$ ) were divided into 2 groups matched in age and BW. For $17 \mathrm{~d}$, rats received the same milk diets (BT and CO) as calves and had free access to water. Milk diets were given in a semiliquid form by reducing water dilution $(2: 1 ; \mathrm{wt} / \mathrm{wt})$ to allow an easier feeding. Rats of each group were adapted to the experimental diets during the first $7 \mathrm{~d}$ of the experiment. Dry matter intake was controlled all along the experimental period. Rats were pair-fed to ensure a similar feed intake for the 2 experimental groups. This study was carried out in accordance with French recommendations and with the guidelines of the Animal Care and Use Committee of INRA for the use of experimental animals including animal welfare and appropriate conditions (Guidelines, April 18, 1988).

\section{Tissue Sampling}

Liver and small intestine tissue samples were taken in the morning from animals in the post absorptive state by surgical biopsies under general anesthesia (isoflurane, $2 \%$, at $0.5 \mathrm{~L} / \mathrm{min}$ for calves; diethyl ether for rats). Liver samples were quickly weighed, rinsed in ice-cold saline solution $(\mathrm{NaCl}, 9 \mathrm{~g} / \mathrm{L})$, cut into small pieces, and frozen in liquid nitrogen. The small intestine was removed and cut into 3 major portions, i.e., duodenum, jejunum, and ileum. The jejunal portion was divided into 3 fractions corresponding to the proximal, medial, and distal jejunum parts with respect to their position relative to the duodenum. The procedure used for the fractionation of the small intestine was the same for all the animals of a species. The 5 intestinal fractions (duodenum, proximal jejunum, medial jejunum, distal jejunum, and ileum) were rinsed thoroughly by injecting ice-cold saline solution $(\mathrm{NaCl}, 9 \mathrm{~g} / \mathrm{L})$ with a syringe, weighed, cut into small pieces, and frozen in liquid nitrogen. Liver and intestine samples were stored at $-80^{\circ} \mathrm{C}$ until subsequent analysis.

\section{Quantification of MTP Subunits by Western Blot Analysis}

Tissue samples ( $1 \mathrm{~g}$ for rats and $3 \mathrm{~g}$ for calves) were homogenized, either with a dounce homogenizer (liver samples) or with a Polytron, twice at $15,000 \mathrm{rpm}$ for $30 \mathrm{~s}$ (intestinal samples) in 3 volumes of $50 \mathrm{~m} M$ Tris (pH 7.4), $250 \mathrm{~m} M$ sucrose, and $1 \mathrm{~m} M$ EDTA supplemented with peptidase inhibitors $(5 \mu \mathrm{g} / \mathrm{mL}$ leupeptin, $1 \mathrm{~m} M$ benzamidine, and $1 \mathrm{~m} M$ phenylmethylsulfonyl fluoride). Total protein contents in homogenates were determined by colorimetry. Cellular MTP large subunit and PDI contents were determined in tissue homogenates by Western blot analysis from an aliquot of total proteins $(50 \mu \mathrm{g}$ for the rat liver and $100 \mu \mathrm{g}$ for the intestinal tissues and calf liver) separated on a $7.5 \%$ SDS-PAGE. Immunoblot analysis was performed using 
Table 2. Body weight, daily weight gain, and absolute and relative weights of the liver and the small intestine of preruminant calves and growing rats fed either beef tallow- (BT) or coconut oil- (CO) based diets. ${ }^{1}$

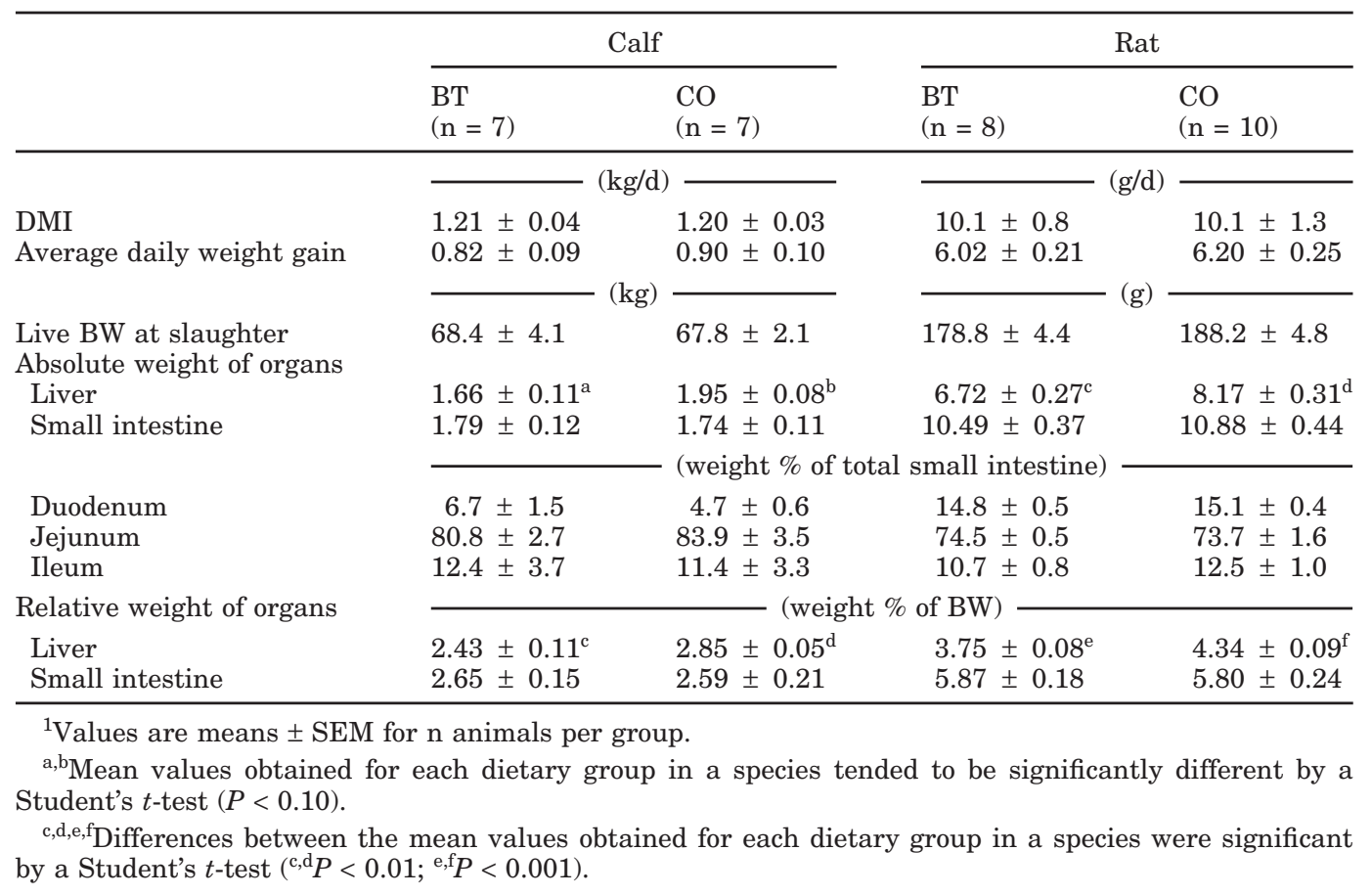

an antisera against the bovine MTP complex (final dilution 1:1000) (Wetterau et al., 1992) and an antirabbit IgG linked with horseradish peroxidase (final dilution 1:10,000). Antibodies were revealed by a light-based detection system using the ECL Western blotting kit. Membranes were exposed to hyperfilms for $3 \mathrm{~min}$ for MTP large subunit and $15 \mathrm{~s}$ for PDI. Signals were quantified by densitometric analysis of autoradiographies (Hoeffer Gs 300; Hoeffer Scientific Instruments, San Francisco, CA).

\section{Analytical Techniques}

Fat droplets in the hepatocytes were characterized by Oil Red O staining of liver slices $(10 \mu \mathrm{m})$ frozen into isopentane (Bouma et al., 1979). Total lipids of liver samples ( $3 \mathrm{~g}$ ) were extracted according to the method of Folch et al. (1957). The TAG content was determined by the enzymatic method using a BioMérieux reagent kit (PAP 150, BioMérieux, Charbonnières-les-Bains, France) according to the method previously described (Leplaix-Charlat et al., 1996). Phospholipid content was determined by colorimetry after mineralization of inorganic $\mathrm{P}$ according to the method of Bartlett (1959). Total cholesterol was measured enzymatically using a reagent kit (CHOD-iodide; Merck, Darmstadt, Germany).

\section{Statistical Analysis}

The values of densitometric signals were corrected for the quantity of protein loaded on the gel electrophoresis, and the values obtained were expressed in densitometric arbitrary units (DAU) per $\mu \mathrm{g}$ of tissue proteins to compare MTP subunit contents between tissues and species. Finally, values were also expressed in DAU per gram of tissue wet weight to test the $\mathrm{CO}$ effect on the values of MTP content in tissues. The significance of differences between values obtained was tested by a Student's $t$-test.

\section{RESULTS}

\section{Animal Performances}

Animals of each group (BT and CO) in each animal species (bovine and rat) had equivalent feed intake throughout the experimental period and presented similar average daily weight gain (Table 2). The relative weight of the liver (expressed in $\mathrm{g} / 100 \mathrm{~g} \mathrm{BW}$ ) was higher in the calves fed CO than in the calves fed BT $(P<0.01)$ and was higher in the rats fed $\mathrm{CO}$ than in the rats fed BT $(P<0.001)$. In contrast, the absolute or relative weight of the small intestine was not different between the experimental groups of calves or of rats (Table 2). In our experimental conditions, relative weights of the 
CALF TISSUES

A

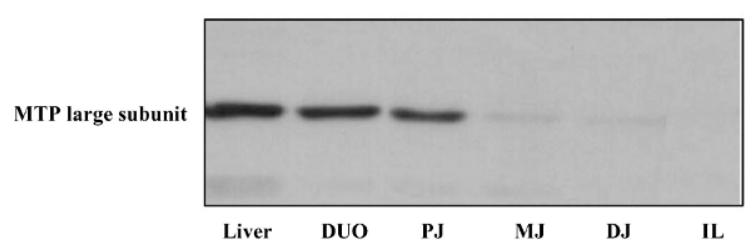

B

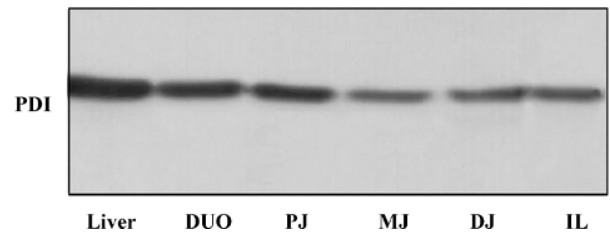

RAT TISSUES

C

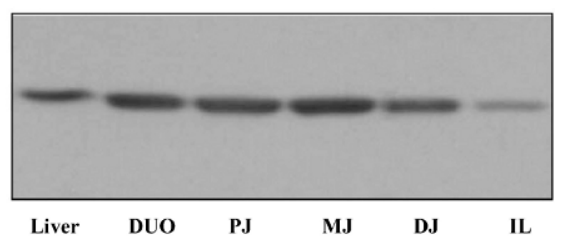

D

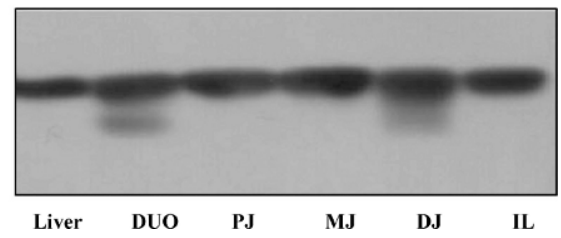

Figure 1. Representative autoradiographies of microsomal triacylglycerol transfer protein (MTP) large subunit and protein disulfide isomerase (PDI) immunodetection in the liver and in small intestine portions from preruminant calves and growing rats. Total proteins (50 $\mu \mathrm{g}$ for rat liver and $100 \mu \mathrm{g}$ for other tissues) from homogenate of the liver, duodenum (DUO), proximal jejunum (PJ), medial jejunum (MJ), distal jejunum (DJ), and ileum (IL) from a preruminant calf (A, B) and a growing rat (C, D) were separated by SDS-PAGE. The MTP large subunit (A, C) and PDI (B, D) contents were immunolocalized. A and C represent autoradiographies that were exposed to hyperfilms for 1 min. B and D represent autoradiographies that were exposed to hyperfilms for $15 \mathrm{~s}$.

different intestinal portions (duodenum, jejunum, and ileum) were similar, the major portion being the jejunum (calf $=82 \%$; rat $=74 \%$ ), with the duodenum representing 5 to $7 \%$ in the calf and $15 \%$ in the rat and the ileum 11 to $12 \%$ for the both animal species.

\section{Tissue Distribution of MTP Subunits}

The MTP expression in tissue samples was characterized by using antisera raised against MTP complex. For this reason, 2 signals were identified after Western blotting of total proteins from homogenates of liver and of small intestine, as shown in a representative autoradiography from a BT-fed calf (Figure 1, A and B). The lightest band, with the apparent molecular weight of $88 \mathrm{kDa}$, corresponded to the large subunit of MTP (Figure 1A). The second band, with the apparent molecular weight of $58 \mathrm{kDa}$, very deep, corresponded to the small subunit of MTP, i.e., the PDI (Figure 1B). In rat intestine and liver tissues, the use of the antisera antibovine MTP also gave 2 signals, corresponding to the same molecular weights as those found in the calf tissues (Figure 1, C and D), and revealing an accurate specificity of the antibody and a good conservation of the molecular weights of the 2 subunits between rat and calf.

Determination of tissue distribution of large and small MTP subunits was based on the mean values obtained from calves and from rats fed the BT milk diet (Table 3 ). In both calf and rat, preliminary experiments have shown that MTP large subunit was not detectable in the ileum. Consequently, PDI content was determined only in tissues exhibiting a signal for the large subunit in both species.

Calf tissues. In the calf, large MTP subunit was detectable at levels not significantly different in the liver, duodenum, proximal jejunum, and medial jejunum tissue samples. However, the amount of PDI subunit was significantly higher in the liver than in the intestinal fractions $(P<0.05)$.

Rat tissues. In fractions of the rat small intestine, MTP large subunit and PDI presented similar profiles of expression (Table 3), the medial jejunum fraction exhibiting the higher content of the 2 subunits of MTP. The amounts sharply decreased in the distal jejunum, where they represented only $50 \%$ of those in the medial jejunum $(P<0.05)$. The proximal part of the small intestine (duodenum and proximal jejunum) presented intermediary values between those of the medial jejunum and distal jejunum. In the rat liver, the content of the large subunit of MTP was close to that in duodenum and proximal jejunum, whereas the PDI content in the liver was similar to that in medial jejunum (Table 3 ).

Comparison between rat and calf tissues. In calf tissues, MTP large subunit contents ranged from 0.45 to $0.96 \mathrm{DAU} / \mu \mathrm{g}$ protein (Table 3 ). In contrast, rat tissue values ranged from 6.94 in the duodenum fraction to 9.41 DAU/ $\mu \mathrm{g}$ proteins in the proximal jejunum fraction. The mean ratio between rat and calf MTP large subunit content in tissues varied from 19.6 in the medial jejunum $(P<0.001)$ to 9.8 in the proximal jejunum $(P<$ $0.001)$ and the liver $(P<0.01)$. 
Table 3. Microsomal triacylglycerol transfer protein (MTP) large subunit and protein disulfide isomerase (PDI) contents in the liver and the small intestine portions of calves and rats fed the beef tallow based diet. ${ }^{1}$

\begin{tabular}{llcc}
\hline & Calf & Rat & $P<^{2}$ \\
\cline { 2 - 4 } & \multicolumn{2}{l}{$\left(\mathrm{DAU}^{3} / \mu\right.$ g total } & proteins $)$ \\
\cline { 2 - 3 } MTP large subunit content & $(\mathrm{n}=7)$ & $(\mathrm{n}=8)$ & \\
Liver & $0.73 \pm 0.10$ & $7.27 \pm 1.28^{\mathrm{bc}}$ & 0.01 \\
Duodenum & $0.45 \pm 0.14$ & $6.94 \pm 1.22^{\mathrm{abc}}$ & 0.01 \\
Proximal jejunum & $0.96 \pm 0.28$ & $9.41 \pm 1.52^{\mathrm{ab}}$ & 0.001 \\
Medial jejunum & $0.50 \pm 0.23$ & $9.80 \pm 1.13^{\mathrm{a}}$ & 0.001 \\
Distal jejunum & traces & $4.85 \pm 0.85^{\mathrm{c}}$ & \\
Ileum & $\mathrm{ND}$ & $\mathrm{ND}$ & \\
PDI content & $(\mathrm{n}=7)$ & $(\mathrm{n}=7)$ & 0.001 \\
Liver & $67.2 \pm 6.0^{\mathrm{a}}$ & $115.7 \pm 5.2^{\mathrm{a}}$ & 0.001 \\
Duodenum & $23.3 \pm 5.6^{\mathrm{b}}$ & $71.3 \pm 8.7^{\mathrm{bc}}$ & 0.001 \\
Proximal jejunum & $31.7 \pm 5.3^{\mathrm{b}}$ & $79.3 \pm 7.1^{\mathrm{b}}$ & 0.01 \\
Medial jejunum & $28.6 \pm 9.8^{\mathrm{b}}$ & $106.0 \pm 16.1^{\mathrm{ab}}$ & \\
Distal jejunum & $\mathrm{NQ}$ & $51.5 \pm 9.4^{\mathrm{c}}$ & \\
Ileum & $\mathrm{NQ}$ & $\mathrm{NQ}$ & \\
\hline
\end{tabular}

${ }^{1}$ Values were means $\pm \mathrm{SE}$ for $\mathrm{n}$ animals per group.

${ }^{2}$ Species difference.

${ }^{3} \mathrm{DAU}=$ Densitometric arbitrary unit.

${ }^{4} \mathrm{ND}=$ Nondetectable.

${ }^{5} \mathrm{NQ}=$ Nonquantified.

${ }^{\mathrm{a}, \mathrm{b}, \mathrm{c}}$ Values without common superscript in a column were significantly different at $P<0.05$.

Similarly, PDI contents were higher in the rat than in the calf, whatever the tissue studied (Table 3). However, the mean ratio of PDI content between rat and calf varied from 3.7 in the medial jejunum to 1.7 in the liver. This ratio was far lower for PDI than for the large subunit of the MTP complex; however, the differences in the values of PDI content between the 2 species remained highly significant, whatever the tissues considered.

\section{Effects of CO Feeding on Hepatic Lipid and MTP Subunit Contents}

Lipid content and composition in the liver. Liver slices of calves and rats were treated by Oil Red O staining to reveal the lipid deposits in hepatocytes. Hepatocytes of CO-fed calves contained numerous fat (red) droplets (Figure 2B), whereas slices from BT calves did not reveal any lipid accumulation in hepatocytes (Figure 2A). In contrast, in the rat liver, little fat droplets were barely observed in the $\mathrm{CO}$ group (Figure 2D) but were totally absent in the BT group (Figure 2C).

Total hepatic lipids were quantified gravimetrically, and their composition into major lipid classes (TAG, phospholipid, and total cholesterol) was determined by enzymatic methods in calves and rats given $\mathrm{CO}$ or BT diets (Table 4). Total lipid content was 2.1-fold higher $(P<0.01)$ in CO-fed calves than in BT-fed calves. This lipid accumulation was explained by the 12 -fold increase of TAG content in CO-fed calves vs. BT-fed calves ( 40.1 vs. $3.3 \mathrm{mg} / \mathrm{g}$ of fresh liver, $P<0.01$ ). In calves, hepatic contents in phospholipid, total cholesterol, and proteins were similar in the both groups. In rats, the $\mathrm{CO}$ diet induced a slight but significant increase of total proteins $(\times 1.1, P<0.001)$ and lipids $(\times 1.2, P<0.05)$. Analysis of liver lipid composition of rats showed that a slight increase in total lipid content of $\mathrm{CO}$ rats resulted in increases in both phospholipid $(\times 1.1, P<0.05)$ and TAG $(\times 1.7, P<0.05)$ contents (Table 4$)$.

Total lipids and their major classes were also quantified in the different portions of the small intestine in both species. No lipid accumulation was observed either in rat or in calf tissues (data not shown).

MTP subunit contents in the liver. The hepatic content of the large subunit of MTP (expressed as DAU per $\mu \mathrm{g}$ of total protein) was not modified by the FA composition of the diet, in both species (Table 5). Similarly, no difference was noted in the different portions of the intestine studied (data not shown). In the rat liver, the PDI content was 1.67 -fold higher $(P<0.01)$ in the $\mathrm{CO}$ than in the BT rats (Table 5), whereas no significant difference was observed between the 2 groups of calves. Quantification of the PDI content in the different portions of the small intestine showed no difference in calves and rats fed the BT and the $\mathrm{CO}$ diets (data not shown).

\section{DISCUSSION}

\section{Tissue Distribution of MTP Subunits}

In the present study, the amount of MTP subunits in the liver tissue and in different portions of the small 
CALF LIVER

A

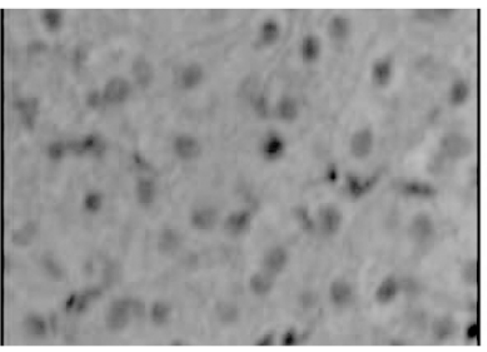

B

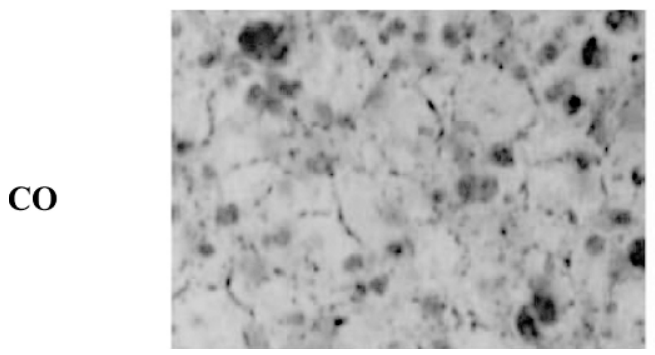

RAT LIVER

C

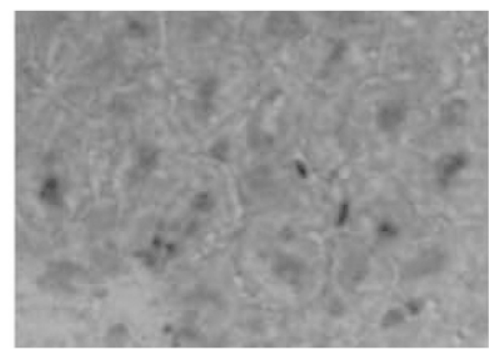

D

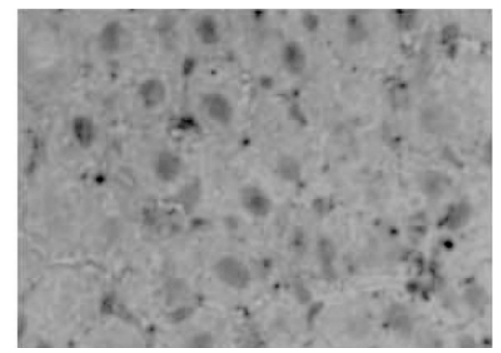

Figure 2. Characterization of the lipid deposits by Oil Red O staining in hepatocytes from preruminant calves and growing rats fed either the beef tallow (BT) or the coconut oil $(\mathrm{CO})$ diets $(\times 120)$. Liver samples from preruminant calves $(\mathrm{A}, \mathrm{B})$ and growing rats $(\mathrm{C}, \mathrm{D})$ fed either the BT (A, C) or the CO (B, D) milk diets were frozen into isopentane and cut into slices of $10 \mu \mathrm{m}$ thickness. Lipid deposits into hepatocytes were revealed by Oil Red O staining according to the method described by Bouma et al. (1979).

intestine was determined by an immunoblot method using a rabbit antibody raised against MTP complex previously validated by Wetterau et al. (1992). The PDI content, in our experimental conditions, was much higher than that of MTP large subunit for both liver and small intestine tissues, as previously reported (Wetterau et al., 1990). This could be related to the multiple roles of the PDI (alone or as part of a proteic complex) into tissues, especially in the correct folding of proteins by disulfide bond formation (Mikami et al., 1998).

In mammal species, the jejunum is the major site of absorption of products resulting from lipid digestion (Noble, 1979). Microsomal TAG transfer protein is implicated in the assembly of chylomicrons into enterocytes and VLDL into hepatocytes by carrying TAG to

Table 4. Contents of total proteins and of total and specific classes of lipids in the liver of preruminant calves and growing rats fed either the beef tallow- (BT) or the coconut oil- (CO) based diets. ${ }^{1}$

\begin{tabular}{|c|c|c|c|c|}
\hline & \multicolumn{2}{|c|}{ Calf } & \multicolumn{2}{|c|}{ Rat } \\
\hline & $\begin{array}{l}\mathrm{BT} \\
(\mathrm{n}=7)\end{array}$ & $\begin{array}{l}\mathrm{CO} \\
(\mathrm{n}=7)\end{array}$ & $\begin{array}{l}\mathrm{BT} \\
(\mathrm{n}=8)\end{array}$ & $\begin{array}{l}\mathrm{CO} \\
(\mathrm{n}=10)\end{array}$ \\
\hline & \multicolumn{4}{|c|}{$\longrightarrow(\mathrm{mg} / \mathrm{g}$ of fresh liver $)$} \\
\hline Total proteins & $95.1 \pm 5.7$ & $95.0 \pm 5.9$ & $117.9 \pm 2.2^{\mathrm{e}}$ & $131.6 \pm 2.6^{\mathrm{f}}$ \\
\hline Total lipids & $31.1 \pm 1.7^{\mathrm{c}}$ & $66.7 \pm 8.4^{\mathrm{d}}$ & $40.3 \pm 1.6^{\mathrm{a}}$ & $48.2 \pm 2.4^{\mathrm{b}}$ \\
\hline Phospholipids & $24.3 \pm 1.1$ & $22.8 \pm 1.6$ & $28.3 \pm 0.8^{\mathrm{a}}$ & $32.1 \pm 1.2^{\mathrm{b}}$ \\
\hline Total cholesterol & $3.45 \pm 0.45$ & $3.87 \pm 0.30$ & $3.40 \pm 0.11$ & $3.29 \pm 0.08$ \\
\hline Triacylglycerols & $3.32 \pm 0.84^{\mathrm{c}}$ & $40.07 \pm 8.64^{\mathrm{d}}$ & $7.15 \pm 0.66^{\mathrm{a}}$ & $12.13 \pm 1.82^{\mathrm{b}}$ \\
\hline
\end{tabular}

${ }^{1}$ Values are means $\pm \mathrm{SE}$ for $\mathrm{n}$ animals per group.

a,b,c,d,e,f Differences between the mean values obtained for each dietary group in a species were significant by a Student's $t$-test $\left({ }^{\mathrm{a}, \mathrm{b}} P<0.05 ;{ }^{\mathrm{c}, \mathrm{d}} P<0.01\right.$; $\left.{ }^{\mathrm{e}, \mathrm{f}} P<0.001\right)$. 
Table 5. Microsomal triacylglycerol transfer large subunit and protein disulfide isomerase (PDI) contents in the liver of preruminant calves and growing rats fed either the beef tallow- (BT-) or the coconut oil(CO-) based diets. ${ }^{1}$

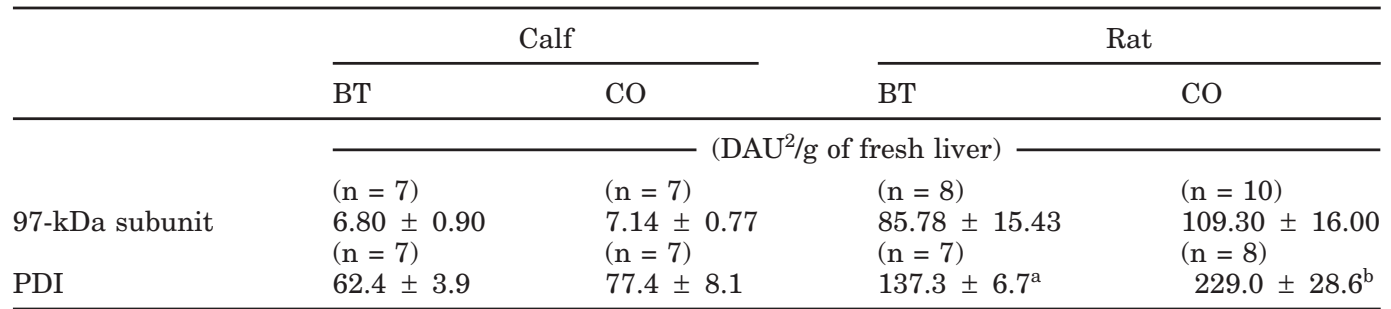

\footnotetext{
${ }^{1}$ Data are means $\pm \mathrm{SE}$ of $\mathrm{n}$ animals.

${ }^{2} \mathrm{DAU}=$ Densitometric arbitrary unit.

${ }^{\mathrm{a}, \mathrm{b}}$ Differences between the mean values obtained for each dietary group in a species were significant by a Student's $t$-test at $P<0.01$.
}

nascent apo B (Bakillah and El Abbouyi, 2003). In our experimental conditions, the expression of MTP large subunit in the small intestine was maximal in the proximal and medial sections of the jejunum, which corresponded to the major site for absorption of dietary lipids and for secretion of dietary FA (as TAG) as part of chylomicrons. These observations agreed with MTP distribution in the intestine reported in the hamster (Lin et al., 1994). However, in the hamster, significant amounts of MTP were also measured in the ileum and the proximal colon, indicating a possible lipid absorption in the distal fractions of the digestive tract. In contrast, in our experimental conditions, MTP expression cannot be measured in the large intestine of the calf, as the large subunit of the complex was undetectable in the ileum onward.

In the liver, MTP large subunit was present in amounts close to that measured in the small intestine of rat and of bovine, in agreement with data earlier reported in hamster (Lin et al., 1994). Nevertheless, our results in the rat differed with other data obtained on this species, showing a higher MTP activity in the liver than in the intestinal mucous membrane (Wetterau and Zilversmit 1986). However, those researchers recorded a large variability in the intestinal MTP activity among animals, probably due to apparent difficulties in the method of mucous membrane preparation by scraping.

The expression of PDI in the small intestine followed a quite similar pattern to that of the large subunit of MTP complex, in both bovine and rat animals. However, in contrast to the large subunit of the MTP complex, the content of PDI was higher in the liver than in the small intestine. Indeed, in the bovine, PDI activity was shown to be mostly distributed in tissues that secrete large amounts of proteins containing disulfide bonds, such as the lymphatic glands, testis, or liver (De Lorenzo and Molea, 1967). Higher PDI activity was also reported in the liver than in the muscles, lung, brain, or kidney of rat and sheep (Brockway et al., 1982), but PDI activity in the intestine was not determined simultaneously. From these data, we could speculate that PDI activity was relatively high in the intestine, as this organ is able to produce high amounts of proteins for the secretion into the lumen of the digestive tract or into lymphatic and blood systems or for the turnover of enterocytes.

\section{Comparison of MTP Contents Between Calf and Rat Tissues}

The amino acid sequence of the MTP 97-kDa subunit is known to be relatively similar among the mammal species (86\% of identity between deduced sequences from human, bovine, hamster, and mouse) (Wetterau et al., 1997). The physico-chemical properties of transfer activities of MTP isolated from the rat liver have been reported to be close to those isolated from the bovine liver (Wetterau and Zilversmit, 1986). Moreover, differences in activity of hepatic MTP among 6 species have been reported recently (Bremmer et al., 1999). In this latter study, duodenal and hepatic MTP activities were not significantly different between rat and cow. Conversely, in the present study, rat tissues presented larger amounts of MTP than calf tissues, suggesting a higher MTP activity in the rat than in the bovine when these animals had received the same milk-based diet especially rich in saturated FA provided by CO. Different hypotheses might be proposed to explain discrepancies between the results of Bremmer et al. (1999) and the present data. First, Bremmer et al. (1999) measured MTP activity in the liver of adult bovines and adult rats, whereas in the present experiment MTP mass was compared between preruminant calves and growing rats. There is no evidence demonstrating that MTP gene expression is similar between growing and adult animals. Moreover, animals used in the study of Bremmer et al. (1999) were fed maintenance diets containing 
$8 \%$ fat, whereas in our experimental conditions the growing animals were fed diets containing $22.4 \%$ fat. It might be supposed that a high fat diet $(22.4 \%)$ may stimulate MTP gene expression in rat liver but not in bovine liver. Finally, it is possible that there is no direct correlation between MTP mass and MTP activity, as previously proposed by Bremmer et al. (2000a).

In the present study, marked differences in liver and small intestine MTP contents between bovine and rat involve both PDI and $97-\mathrm{kDa}$ subunits of the complex. However, they are more important for the large subunit than for the PDI. This could be explained by the ubiquitous role and expression of PDI. Differences in MTP content between rat and bovine observed in some portions of the small intestine were not due to differences in feed intake. Indeed, when corrected for the metabolic weight of the animals, MTP intestinal contents were slightly higher for bovine than for rat. However, in the liver, the $97-\mathrm{kDa}$ subunit content was nearly 10 -fold higher in rat than in bovine, which would indicate a better ability of the rat to carry on liver TAG to the endoplasmic reticulum site of VLDL assembly and would explain the low ability of bovine liver to secrete TAG as part of VLDL particles (Pullen et al., 1990; Graulet et al., 1998).

\section{Effects of Dietary CO on Intestinal and Liver TAG Metabolism}

To address the previous hypothesis, the second aim of this study was to elucidate the metabolic mechanisms involved in the development of hepatic steatosis in preruminant calves fed a milk substitute containing $\mathrm{CO}$ as the sole source of lipids (Jenkins and Krammer, 1986; Bauchart et al., 1999). By in vitro experiments using incubated liver slices, we demonstrated that dietary $\mathrm{CO}$ in preruminant calves reduced FA oxidation by hepatocytes, favoring TAG synthesis without stimulation of TAG secretion (Graulet et al., 2000). Under the same dietary conditions, we showed a reduction in hepatic apo B content (Gruffat-Mouty et al., 2001), which could be explained partly by a reduction of TAG availability at the site where VLDL assembly proceeded and consequently by a lack of protective effect of TAG on nascent apo B (Bakillah and El Abbouyi, 2003).

The present experiment showed that CO-fed calves developed a lipid infiltration close to steatosis in hepatocytes, as previously described by Jenkins and Kramer (1986). This induced liver hypertrophy caused by a dramatic accumulation of TAG as cellular fat droplets in hepatocytes. In CO-fed rats, weight of the liver also increased because of the slight and concomitant rise of cellular protein, phospholipid, and TAG contents, but rats did not develop a liver steatosis.
One possible explanation of these discrepancies in hepatic metabolism between calves and rats could be a better efficiency of calves to absorb and transport FA, inducing a higher uptake of FA by the liver. However, the daily weight gain of rats fed CO and BT, close to 6 $\mathrm{g} / \mathrm{d}$, corresponded to normal values for growing rats, indicating that nutrients and especially FA provided by the experimental milk diets were efficiently used by the animals.

Another potential explanation of differences in hepatic lipid metabolism between calf and rat would be the role of MTP. Indeed, in humans, a defective MTP activity has already been reported in patients suffering from hepatic steatosis associated with abetalipoproteinemia, a rare autosomal disease affecting assembly and secretion of apo B containing lipoproteins in the intestine and the liver (Wetterau et al., 1997). Furthermore, the concomitant expression of apo B and MTP in a heterologous cell system allows the secretion of apo B-containing lipoproteins, indicating the addition of sufficient TAG to form a lipoprotein particle (Wetterau et al., 1997). All these data confirm the essential role of MTP activity in the secretion of TAG. In our experimental conditions, the low hepatic content of MTP in calf compared with that in rat let us speculate that MTP could be considered as a good candidate among limiting factors for the hepatic secretion of VLDL in bovine animals.

The regulation of tissue MTP activity by dietary FA has been less studied. In the hamster, Bennett et al. (1995) showed that the hepatic content of MTP large subunit mRNA increased when dietary lipids were richer in saturated FA (14:0 and 16:0) than in unsaturated FA (18:1 n-9 and 18:2 n-6). However, our results did not reproduce those of Bennett et al. (1995), probably because of differences in experimental conditions such as the source of dietary lipids (artificial sources containing only 2 purified FA vs. complex lipid sources such as BT or CO), the species-specific characteristics (rat and bovine vs. hamster), the parameters measured (MTP large subunit protein vs. mRNA), and the length of the feeding trials ( 28 vs. $19 \mathrm{~d}$ ).

According to our experimental design, 3 distinct results could have been expected concerning MTP content in the liver of CO-fed calves compared with BT-fed calves. First, MTP content in the liver of calves fed CO would be increased compared with that in the liver of calves fed BT. This would have clearly indicated that MTP expression was regulated by the nature of the dietary FA or by the liver TAG content and was not, consequently, the limiting factor for VLDL secretion by calf hepatocytes. Second, MTP content would be lower in calves fed $\mathrm{CO}$ than in calves fed BT, suggesting that the MTP protein and activity were limiting for TAG 
secretion in conditions where their synthesis was stimulated (Graulet et al., 2000). Indeed, such a situation has already been observed in the liver of dairy cow, where MTP activity decreases on the days before calving concomitantly with the increase of liver TAG content (Bremmer et al. 2000a). Finally, we observed a third case, which was the lack of significant modification in the MTP large subunit content by CO diet compared with BT diet, either in preruminant calf or in growing rat. This would indicate that the expression of MTP 97-kDa subunit was not regulated by dietary FA independent of variations in the hepatic metabolism of TAG. This result was in agreement with recent findings of Bremmer et al. (2000a) showing the lack of modification of MTP activity in response to the increase in hepatocyte TAG content in dairy cattle. Moreover, those researchers have also demonstrated that MTP activity was not modulated by the increase in liver TAG content occurring after a large FA uptake, both by in vivo and in vitro experiments (Bremmer et al., 2000b).

Based on current knowledge, 2 hypotheses explaining our current results could be proposed. First, MTP gene expression was low in calf (in comparison to rat) but sufficient for TAG export in classical nutritional conditions (BT diet). However, when liver TAG synthesis increased, MTP would become a limiting factor of TAG secretion because its gene expression was constitutive and poorly modulatable. Second, the low capacity of bovine liver to secrete TAG was directly linked to a low capacity for delivery of TAG stored in cytosol (poor TAG hydrolase or microsomal DGAT activities) (Gilham et al., 2003). This could limit TAG availability in the lumen of the endoplasmic reticulum where VLDL assembly occurred.

In conclusion, the present study clearly showed that liver MTP content was lower in calf than in rat but was not modified by dietary FA source in both species, even though CO feeding led to hepatic TAG accumulation in calf liver. Present experimental conditions did not allow proof that MTP expression was directly related to the accumulation of fat in calf liver. Consequently, further experiments are needed to assess the role of MTP in liver steatosis observed under different nutritional and physiological conditions in bovine animals.

\section{AKNOWLEDGMENTS}

The authors wish to gratefully acknowledge Lawrence Aggerbeck (CNRS, Centre de Génétique Moléculaire, Gif-sur-Yvette) for providing us the bovine MTP antibody, Marie Elisabeth Bouma-Samson and Nicole Vertier for advice on the characterization of TAG deposits by Oil Red staining, Françoise Duboisset and Cécile Piot for their efficient technical assistance, René
Souchet and Christian Leoty for maintenance and care of the calves, Jacques Lefaivre for animal surgery, and Christine Cubizolles and her group for the maintenance and care of the rats (INRA, Unite Expérimentale de Nutrition Comparée, Theix).

\section{REFERENCES}

Bakillah, A., and A. El Abbouyi. 2003. The role of microsomal triglyceride transfer protein in lipoprotein assembly: An update. Front. Biosci. 8:294-305.

Bartlett, G. R. 1959. Phosphorus assay in column chromatography. J. Biol. Chem. 234:466-468.

Bauchart, D., D. Durand, D. Gruffat-Mouty, C. Piot, B. Graulet, Y. Chilliard, and J. F. Hocquette. 1999. Transport sanguin et métabolisme tissulaire des lipides chez le veau de boucherie. INRA Prod. Anim. 12:273-285.

Bennett, A. J., M. A. Billett, A. M. Salter, and D. A. White. 1995. Regulation of hamster hepatic microsomal triglyceride transfer protein mRNA levels by dietary fats. Biochem. Biophys. Res. Commun. 212:473-478.

Bennett, A. J., J. S. Bruce, A. M. Salter, D. A. White, and M. A. Billett. 1996. Hepatic microsomal triglyceride transfer protein messenger RNA concentrations are increased by dietary cholesterol in hamsters. FEBS Lett. 394:247-250.

Berriot-Varoqueaux, N., L. P. Aggerbeck, M. E. Samson-Bouma, and J. R. Wetterau. 2000. The role of the microsomal triglyceride transfer protein in abetalipoproteinemia. Annu. Rev. Nutr. 20:663-697.

Billett, M. A., J. S. Bruce, D. A. White, A. J. Bennett, and A. M. Salter. 2000. Interactive effects of dietary cholesterol and different saturated fatty acids on lipoprotein metabolism in the hamster. Br. J. Nutr. 84:439-447.

Bouma, M. E., N. Amit, and R. Infante. 1979. Ultrastructural localization of apo-b and apo-c binding to very low density lipoproteins in rat liver. Virchows Arch. B Cell Path. 30:161-180.

Bremmer, D. R., S. J. Bertics, S. A. Besong, and R. R. Grummer. 2000a. Changes in hepatic microsomal triglyceride transfer protein and triglyceride in periparturient dairy cattle. J. Dairy Sci. 83:2252-2260.

Bremmer, D. R., S. J. Bertics, and R. R. Grummer. 1999. Differences in activity of hepatic microsomal triglyceride transfer protein among species. Comp. Biochem. Physiol. 124:123-131.

Bremmer, D. R., S. L. Trower, S. J. Bertics, S. A. Besong, U. Bernabucci, and R. R. Grummer. 2000b. Etiology of fatty liver in dairy cattle: effects of nutritional and hormonal status on hepatic microsomal triglyceride transfer protein. J. Dairy Sci. 83:2239-2251.

Brockway, B. E., S. J. Foster, R. B. Freedman, and D. A. Hillson. 1982. The distribution of protein disulphide-isomerase activity in mammalian tissue. Biochem. Soc. Trans. 10:115-116.

Chen, D., and R. Grummer. 2001. Gene therapy for bovine fatty liver: possibilities and problems - a review. Asian-Aust. J. Anim. Sci. 14:1331-1341.

De Lorenzo, F., and G. Molea. 1967. Relative levels of the disulfideinterchange enzyme in the microsomes of the bovine tissues. Biochim. Biophys. Acta 146:593-595.

Durand, D., and D. Bauchart. 1986. Variations nycthémérales de la lipémie et de la glycémie au niveau des voies afférentes et efférentes du foie chez le veau préruminant. Reprod. Nutr. Dev. 26:371-372.

Emery, R. S., J. S. Liesman, and T. H. Herdt. 1992. Metabolism of long-chain fatty acids by ruminant liver. J. Nutr. 122:832-837.

Folch, J., M. Lees, and G. H. S. Sloane-Stanley. 1957. A simple method for the isolation and purification of total lipids from animal tissues. J. Biol. Chem. 226:497-509.

Gilham, D., S. Ho, M. Rasouli, P. Martres, D. E. Vance, and R. Lehner. 2003. Inhibitors of hepatic microsomal triacylglycerol hydrolase decrease very low density lipoprotein secretion. FASEB J. 17:1685-1687. 
Graulet, B., D. Gruffat, D. Durand, and D. Bauchart. 1998. Fatty acid metabolism and very-low density lipoprotein secretion in liver slices from rats and preruminant calves. J. Biochem. 124:1212-1219.

Graulet, B., D. Gruffat, D. Durand, and D. Bauchart. 2000. Effects of milk diets containing beef tallow or coconut oil on the fatty acid metabolism of liver slices taken from preruminant calves Br. J. Nutr. 84:309-318.

Gruffat, D., D. Durand, Y. Chilliard, P. Williams, and D. Bauchart. 1997. Hepatic gene expression of apolipoprotein B100 during early lactation in underfed, high producing dairy cows. J. Dairy Sci. 80:657-666.

Gruffat-Mouty, D., B. Graulet, D. Durand, M. E. Samson-Bouma, and D. Bauchart. 1999. Apolipoprotein B production and verylow density lipoprotein secretion by calf liver slices. J. Biochem. 126:188-193.

Gruffat-Mouty, D., B. Graulet, D. Durand, M. E. Samson-Bouma, and D. Bauchart. 2001. Effects of dietary coconut oil on apolipoprotein B synthesis and VLDL secretion by calf liver slices. Br. J. Nutr. 86:13-19.

Jenkins, K. J., and J. K. G. Kramer. 1986. Influence of low linoleic and linolenic acids in milk replacer on calf performance and lipids in blood plasma, heart and liver. J. Dairy Sci. 69:1374-1386.

Leplaix-Charlat, L., D. Durand, and D. Bauchart. 1996. Effects of diets containing tallow and soybean oil with and without cholesterol on hepatic metabolism of lipids and lipoproteins in the preruminant calf. J. Dairy Sci. 79:1826-1835.

Lin, M. C. M., C. Arbeeny, K. Bergquist, B. Kienzle, D. A. Gordon, and J. R. Wetterau. 1994. Cloning and regulation of hamster microsomal triglyceride transfer protein. J. Biol. Chem. 269:29138-29145.

Mikami, T., R. Genma, K. Nishiyama, S. Ando, A. Kitahara, H. Natsume, T. Yoshimi, R. Horiuchi, and H. Nakamura. 1998. Alterations in the enzyme activity and protein contents of protein disulfide isomerase in rat tissues during fasting and refeeding. Metabolism 47:1083-1088.

Nakamuta, M., B. H. J. Chang, R. Hoogeveen, W. H. Li, and L. Chan. 1996. Mouse microsomal triglyceride transfer protein large subunit: cDNA cloning, tissue-specific expression, and chromosomal localization. Genomics 33:313-316.

Noble, R. C. 1979. Lipid metabolism in the neonatal ruminant. Prog. Lipid Res. 18:179-216.

Pullen, D. L., J. S. Liesman, and R. S. A. Emery. 1990. Species comparison of liver slice synthesis and secretion of triacylglycerol from nonesterified fatty acids in media. J. Anim. Sci. 68:13951399.

Shoulders, C. C., D. J. Brett, J. D. Bayliss, T. M. E. Narcisi, A. Jarmuz, T. T. Grantham, P. R. D. Leoni, S. Bhattacharya, R. J. Pease, P. M. Cullen, S. Levi, P. G. H. Byfield, P. Purkiss, and J. Scott. 1993. Abetalipoproteinemia is caused by defects of the gene encoding the $97 \mathrm{kDa}$ subunit of a microsomal triglyceride transfer protein. Hum. Mol. Genet. 2:2109-2116.

Sugimoto, T., S. Yamashita, M. Ishigami, N. Sakai, K. I. Hirano, M. Tahara, K. Matsumoto, T. Nakamura, and Y. Matsuzawa. 2002. Decreased microsomal triglyceride transfer protein activity contributes to initiation of alcoholic liver steatosis in rats. J. Hepatol. $36: 157-162$.

Tagushi, H., T. Omachi, T. Nagao, N. Matsuo, I. Tokimitsu, and H. Itakura. 2002. Dietary diacylglycerol suppresses high fat dietinduced hepatic fat accumulation and microsomal triacylglycerol transfer protein activity in rats. J. Nutr. Biochem. 13:678-683.

Toullec, R. 1978. Le Veau. Pages 245-274 in Alimentation des Ruminants. Institut National de la Recherche Agronomique Publication, Versailles, France.

Wetterau, J. R., L. P. Aggerbeck, M. E. Bouma, C. Eisenberg, A. Munck, M. Hermier, J. Schmitz, G. Gay, D. J. Rader, and R. E. Gregg. 1992. Absence of microsomal triglyceride transfer protein in individuals with abetalipoproteinemia. Science 258:999-1001.

Wetterau, J. R., K. A. Combs, S. N. Spinner, and B. J. Joiner. 1990 Protein disulfide isomerase is a component of the microsomal triglyceride transfer protein complex. J. Biol. Chem. 265:98009807.

Wetterau, J. R., M. C. M. Lin, and H. Jamil. 1997. Microsomal triglyceride transfer protein. Biochim. Biophys. Acta 1345:136-150.

Wetterau, J. R., and D. B. Zilversmit. 1986. Localization of intracellular triacylglycerol and cholesteryl ester transfer activity in rat tissues. Biochim. Biophys. Acta 875:610-617. 